\title{
SHEDDING NEW LIGHTS ON JAVANESE MYSTICISM: Pegon Manuscripts in the Javanese World ${ }^{1}$
}

\author{
Nur Ahmad \\ Universitas Islam Negeri Walisongo, Semarang \\ Email: n.ahmad@walisongo.ac.id
}

\begin{abstract}
This paper aims to understand the Javanese mystical teachings from the Islamic point of views. By examining the development of Javanese mysticism in the suluk literatures, especially those written in Pegon manuscripts, this paper tries to trace back the position of Islam in the mystical dimension of the Javanese people, especially in the idea of wahdah al-wujūd. This concept teaches the Oneness of God, who is the ultimate source of all existence. Nothing possesses an existence except it is derived from Him. It makes an analogy of creatures and the Creator as the rays of sunshine. Taking all the general Javanese esoteric ideas in the manuscripts studied, the vital point this paper made is that the concept of the unity between the servant and the Lord, which is the deep-rooted doctrine in Java, is genuinely rooted in Islamic teachings. Another finding of this study is concerned with the critical role of pesantren tradition in the dissemination of wahdah alwujūd as clearly shown in many Pegon manuscripts. Therefore, the accusation that the "pantheistic" feature in Javanese mysticism is solely attributed to poets, not Islamic scholars, is rejected.
\end{abstract}

Keywords: javanese mysticism, pegon manuscripts, waḥdah alwujūd

DOI: https://doi.org/10.20414/ujis.v23i2.370

\section{Introduction}

THE SCHOLARLY discussion about the 19th century Islam in Java is complex. Some scholars hold that the Javanese religion was a

${ }^{1}$ This article, at the first version, was presented in Seminar Internasional Pernaskahan Nusantara, "Naskah Kuno sebagai Sumber Ilmu Pengetahuan dan Peradaban Nusantara: Memperteguh Kebhinekaan dan Memperkuat Restorasi Sosial", at Universitas Sebelas Maret, Surakarta, 25-26 September 2017. 
mixed between Hindu-Buddhist tradition with a thin surface of Islam merely as a "cover". This claim is mainly based on "a momentarily of time" without regarding the long-historical development of Islam in the region. ${ }^{2}$ Building his arguments on the practice of people in the "small town in east-central Java", Geertz generalizes what he found as "the religion of Java" which adopts Islamic names with Hindu-Buddhist elements as its core. ${ }^{3}$ He writes, "Buddhist mystic practices got Arabic names, Hindu Radjas suffered a change of title become Moslem Sultans, the common people called some of their spirits jinns, but little else changed."4

The result of other scholars seriously takes issues with Geertz's conclusion. Mas'ud and Hodgson argue that Geertz takes a very dichotomist point of view, namely modernist Islam vis a vis traditional Islam. ${ }^{5}$ It is understandable, therefore, as Hodgson puts it, that Geertz views what is claimed as unaccepted and un-Islamic by the former, as simply Hindu-Buddhist tradition. ${ }^{6}$ In addition,

${ }^{2}$ Marshall G. S. Hodgson, The Venture of Islam Conscience and History in a World Civilization: The Expansion of Islam in the Middle Periods, vol. 2 (Chicago: University of Chicago Press, 1974), 551.

${ }^{3}$ Clifford Geertz, The Religion of Java, Phoenix ed. (Chicago: University of Chicago Press, 1976), 1. Hodgson discusses the difference of "Islamic" as the adjective for everything related to Islam in the religious sense and "Islamicate" for "overall society and culture which associated historically with the religion". From this framework, he criticizes scholars who could not separate the two and falsely associate parts of the culture, which is not - as he describes - "Islamic" in the sense of religious, but "Islamicate" in the history of Islam in a country, with the remaining aspects of old-religions which Islam has appropriated, is its own. For more discussion about Islamic and Islamicate, see Marshall G. S. Hodgson, The Venture of Islam: The Classical Age of Islam, vol. 1 (Chicago: The University of Chicago Press, 1997), 57-60. In this thesis, the two aspects are referred to as Islamic since even in the sense of religious, both expressions are Islamic. For example, in ritual nyadran which is the Islamic version of Hindu-Buddhist tradition sradha, people do not revere their ancestors any more, but they pray to God to forgive them as the expression of good character toward the deceased family.

${ }^{4}$ Geertz, The Religion of Java, 125.

5 Abdurrachman. Mas'ud, Dari Haramain ke Nusantara: Jejak Intelektual Arsitek Pesantren (Jakarta, Indonesia : Kencana, 2006), 8; Hodgson, The Venture of Islam, 2:551.

${ }^{6}$ Hodgson, The Venture of Islam, 2:551. 
having "Geertz's village studies" as his academic foundation, Mark Woodward failed to find any Hindu-Buddhist "philosophy and ritual" of the Javanese people he observed. ${ }^{7} \mathrm{He}$ also criticizes Geertz, who ignored medieval Sufism in the Middle East when examining the Javanese Mystics.

A more moderate view on the Hindu-Buddhist background of the Javanese Islam is given by Judith Becker. ${ }^{8}$ By analyzing the gamelan $^{9}$ ensemble and Javanese dance, she shows the possibility to interpret the inner meaning of the performance from both Tantric tradition and Sufism lens. ${ }^{10}$ Her comprehensive data on Tantric tradition makes it is difficult to doubt that it is because of this similarity that the shift to Sufism understanding is unshaking for Javanese people. Moreover, she shows how the Sufi doctrines have become unseparated and important values to interpret the gamelan stories. ${ }^{11}$

However, it is undeniable that Islam dominated the culture of Java in the 19th century. Pre-Muslim elements, from HinduBuddhist and local religions, are the main text to which Islam Java revises some parts and leaves untouched the others. The development of any religion, even in the first time they were proclaimed by their founders, proves that the idea of borrowing is unavoidable. For Islam, the Prophet Muhammad did not call people of the 7th century Saudi Arabia to Islam in a vacuum. Those who are the first subject of this call already had their culture and tradition. From the very language he used, the idea of borrowing has happened. The term Allahh for Arabian people in this era had had a specific meaning which was not the meaning intended by him as the only God. By the time, slowly but surely, with a tendency to build a new semantical meaning on the old one,

7 Mark R. Woodward, Islam in Java: Normative Piety and Mysticism in the Sultanate of Yogyakarta (Tucson: The University of Arizona Press, 1989), 2.

8 Judith O. Becker, Gamelan Stories: Tantrism, Islam, and Aesthetics in Central Java, 2nd ed., Monographs in Southeast Asian Studies (Arizona: Program for Southeast Asian Studies, Arizona State University, 2004).

${ }^{9}$ Javanese traditional music instruments

${ }^{10}$ Becker, Gamelan Stories, 4.

${ }^{11}$ Ibid., 7. 
changes happened in the term Alläh from the highest God above the other gods to God, the One and the Only.

The same response happens every time Islam faces a new civilization. Does it mean that the next development of Islam is totally determined by these values? It could take - in our case a very long - process that "a religion takes into itself only those ideas, customs and tendencies which are in a one way or another compatible with its inner most essence." 12 To illustrate this meeting of two values, Annemarie Schimmel writes, "the water takes the colour of the glass, or else the 'white radiance of eternity', the colourless Light, becomes visible only in its reflections in ever-changing colours". ${ }^{13}$ It is the process of transforming the Hindu polyandry story of a figure in puppet performance, Drupadi, ${ }^{14}$ who is married to five members of Pandawa, ${ }^{15}$ to become the story of Islamic monogamy of her with her only husband, Yudhistira, the oldest member of Pandawa. It is also the transformation of mandala ${ }^{16}$ that teaches students to become pandhita ${ }^{17}$ to pesantren ${ }^{18}$ that teaches students to become kiai. ${ }^{19}$

12 Annemarie Schimmel, Deciphering the Signs of God: A Phenomenological Approach to Islam (Albany, NY: State University of New York Press, 1994), viii.

${ }^{13}$ Ibid.

${ }^{14}$ A strong, unique, and female character in the epic Mahabarata. In the Indian version of the story, she has five husbands which is a great violation of Islamic law. In the Javanese version, she is married to only one husband, Yudhistira. This "deviation" from the Indic version shows the influence of Islamic teaching on the story.

15 The five characters play the protagonist character in the epic Mahabarata against Kurawa. They are, from the oldest to the youngest, Yudhistira, Bima, Arjuna, Nakula, and Sadewa.

${ }^{16}$ A dormitory for the hermits or learners of the Siwa religion located in the middle of the forest which was led by a religious teacher.

17 The word is derived from Sanskrit. In Javanese language it means a clever or a well-educated person whether in religious or profane matters because the dichotomy of the two collapses in the traditional civilization. For example, Mahabara mentions Pandhita Durna for his excellence in archery. Hamam Supriyadi, "The Meanings of Sanskrit Loanwords in Thai and Javanese Languages," Humaniora 23, no. 3 (2011): 280-289.

18 "Traditional Islamic training centers for advanced students". Zamakhsyari Dhofier, "The Pesantren Tradition: The Role of the Kyai in the 
This article is an effort to evaluate this process of transformation in a specific area within Javanese Islam tradition, namely the mystical dimension. The result of this quest is a call to rethink the development of Islam in Java $19^{\text {th }}$ century that is commonly believed as "the dark times before the awakening" ${ }^{20}$

\section{Early Javanese Mysticism}

Before the so-called "cultural synthesis" of Java and Islam in the reign of Sultan Agung (r. 1613-1646), the mystical dimension of Islam had already permeated deeper into the Javanese realm. ${ }^{21}$ Already in the 16th century, a Javanese primbon (Muslim code of ethics) recognizes its sources as Bidāyah al-Hidāyah of Ghazzālī (d. 505/1111), Rawḍat al-'Ulamā' of al-Zandawaysitī (d. 382/922), and probably Mafātih al-Rajā' fì Sharh Mașābih al-Dujā of al-'Aqūlī alWāṣițī (d. 797/1394). ${ }^{22}$ Another text, supposed to be as old as this text, is "a systematically planned tract dealing with the way a Muslim has to behave". ${ }^{23}$

In addition to that, the rise of suluk literature marked this process. One of the oldest mystical books entitled usul suluk ${ }^{24}$ (the basic principles of mysticism), again, mentions Ghazzālī's Ihyya ' 'Ulūmiddìn and Abū Shakūr al-Sālimī's al-Tamhìd fì bayān al-tawhịd

Maintenance of Traditional Islam in Java," Unpublished Dissertation (The Australian National University, 1999), 280-289.

19 "A title for Muslim scholars in Java who generally lead pesantren institutions". Ibid., 370.

${ }^{20}$ Yumi Sugahara, "Kitab Jawa: Islamic Textbooks Written in Javanese (Pegon)," in Proceedings of the Symposium on Bangsa and Umma: A Comparative Study of People-Grouping Concepts in the Islamic Areas of Southeast Asia: May 12, 13 E 19, Tokyo and Kyoto, vol. 1 (Section for Islamic Area Studies, Institute of Asian Cultures, Sophia University, 2007), 40-48.

${ }^{21}$ See chapter two on Sultan Agung in M. C. Ricklefs, Mystic Synthesis in Java: A History of Islamization from the Fourteenth to the Early Nineteenth Centuries (Norwalk CT: EastBridge Signature Books, 2006), 33-54.

${ }^{22}$ The text is the possession of Leiden Library with code Or. 266. Drewes states that the two first are mentioned clearly in the text, while the third is his supposition on the given Kitab Masabeh Mafateh in the text. G. W. J. Drewes, An Early Javanese Code of Muslim Ethics (The Hague: Nijhoff, 1978), 6.

${ }^{23}$ The text is known as "the Ferrara kropak". Ibid., 4.

${ }^{24}$ The book is attributed to Sunan Bonang, one of the nine saints of Java, that is why it is also called the Book of Bonang. 
as its main sources. ${ }^{25}$ These principles are based primarily on the nature of the Real Being which emphasizes the guiding maxim of the unity of God (Ar. tawhìd). It is achieved through the exposition of Islamic doctrines for example in the two Islamic testimony (Ar. shahādatayn), ${ }^{26}$ the concept of Self-disclosure of God as the goal of the creation, ${ }^{27}$ and the concept of $\bar{i} m \bar{a} n$, tawhìd, and ma'rifah. ${ }^{28}$ It is undoubted from these long explanation that the author of this text follows the Ash arite school in theology and one of the four schools in Islamic Jurisprudence, or in short that the author preaches Sunni Islam. ${ }^{29}$ The text promotes the Ghazzālian school. In this text, no concept nor indication that supports the concept of the degradation of Being (Ar. marātib al-wujūd) is found. On the basis of this fact, Steenbrink which is supported by Nasuhi

${ }^{25}$ It is based on Or. 1928 and Or. 11.092 which are published in G. W. J. Drewes, ed., The Admonitions of Seh Bari: A 16th Century Javanese Muslim Text Attributed to the Saint of Bonan (The Hague: Martinus Nijhoff, 1969), 14. Some parts of the MS also edited and translated in P.J. Zoetmulder, Pantheism and Monism in Javanese Suluk Literature: Islamic and Indian Mysticism in an Indonesian Setting, trans. M.C. Ricklefs (Leiden: KITLV Press, 1995). Formerly, the text is discussed by B.J.O. Schrieke, "Het Boek van Bonang," Thesis (Leiden University, 1916); H. Kraemer, "Een Javaansche Primbon Uit de Zestiende Eeuw," Thesis (Leiden University, 1921). But for this study, only two published versions above are used. The MS. only indicates it as Tamhid. However, it is likely to be Abū Shakūr al-Sālimī's as assumed by both both Schrieke and Kraemer since the text is widely spread in the Archipelago. This Tamhì is not only book in dogmatics as Drewes argues based on the title, when I read the book in Arabic it deals also with gnosis (Ar. ma'rifah). In Islam, it is almost impossible to discuss the concept of the unity of God without in one or another sense examining the concept of ma'rifah. Abū Shakūr Al-Sālimī, al-Tamhīd fì Bayān al-Tawhīd (Delhi, 1892), 3.

${ }^{26}$ Dealing with the first part of this testimony that is "There is no god save God." Drewes, The Admonitions of Seh Bari, 38-41.

${ }^{27}$ Ibid., 41-51. For more detailed discussion on this concept, see William C. Chittick, Self-Disclosure of God: The Principles of Ibn Al-'Arabi's Cosmology (Albany: SUNY Press, 1998).

${ }^{28}$ Drewes, The Admonitions of Seh Bari, 57.

29 This could be seen in the notion of inseparable between Essence and Attributes. Ibid., 58. Meanwhile, the reference to four schools with a strong indication as the accepted schools is found many times, for example, Ibid., 43, 75,77 , and 79 . 
concludes that the early mysticism in Java is that of Ghazzāli school. ${ }^{30}$

For the traditional community in Indonesia, such as Nahdlatul Ulama, Ghazzālī (d. 1111) is the legitimate source of Sufism. The most salient feature of his teaching, as a follower of Ash arism, is to create a moderate position between the speculative mysticism in the one side and the dry legalistic approach on the other side. For example, on the most beautiful verse in the Qur'an about the nature of God, the Light Verse chapter an-Nūr (24) verse 35, he writes a long commentary to establish the nature of God is the Light that makes others exist. ${ }^{31}$ At the same time, however, he negates the pantheistic views and the rigid interpretation that God is "only" the giver of the light. Ghazzāli sets a mysticism in which the tenets of faith on the revelation are defended by reason and dialectic, while the wild speculation of faith is rejected. In other words, he establishes that mysticism must be guided by the sacred law (sharia).

Supposed to be the next development of Javanese mysticism, the concept of wahdah al-wujūd alters the whole face of it. Besides explaining the pillars of Islam seen from the mystical dimension, Suluk Wujil - even though it is also attributed to Sunan Bonang 32 introduces the idea of "the unity of Being". However, the great theme of this text is the spiritual journey of Wujil to achieve the unity of God. Here the saint Bonang is called Ratu Wahdat, which bears the idea of someone who is experts in the knowledge of the unity of Being. ${ }^{33}$ What is condemned in usul suluk is taught in this text. It says:

${ }^{30}$ Karel A. Steenbrink, Beberapa Aspek tentang Islam di Indonesia Abad ke-19 (Jakarta: Bulan Bintang, 1984), 173-174; Hamid Nasuhi, Serat Dewaruci: tasawuf Jawa Yasadipura I (Jakarta: Ushul Press etc, 2009), 227.

${ }^{31}$ Abū Ḥāmid Muḥammad Al-Ghazzālī, Mishkāt al-Anwāò wa Miṣfāt al-Asrār, ed. 'Abd al-'Azīz 'Izz al-Dīn Al-Sayrawān (Beirut: Mazra'at Binābat al-Īmān, 1407).

${ }^{32} \mathrm{He}$ is one of the nine saints of Java (Jav. Walisongo) who are believed as the successful preachers of Islam to the Javanese people in the late $15^{\text {th }}$ century and the early $16^{\text {th }}$ century. He disseminates Islam in the north-coastal area of Java and the interior of East Java.

${ }^{33}$ G. W. J. Drewes, "Javanese Poems, Dealing with or Attributed to the Saint of Bonan," 1968, 213. 
The words là iläha (there is no god) contain an isbat and a nafi; they amount to being and non-being. Such is their meaning.

To God non-being is attributed, (but) in this non-being His Being takes its It is (in) the indefinite word. ${ }^{34}$

Despite its striking resemblance to religious rituals of Javanese, Shiite also influences their mystical doctrines. ${ }^{35}$ We find several written sources that contain a teaching on Fāțimah's testimony (Ar. shahādah Fātimah). In Shiite doctrine, it is known as the third testimony which is chanted in adhān and iqāmah (Muslim's callings to pray).

Text (Or. 5614, pp. 2):

"Punika shahādah Fātimah lamun ora weruh wong lanang lan wong wadon iya iku durung shahadate [damaged, na] imane wong, iyo iku shahadate: Ashhadu an lā ilāha illallāh wa asyhhadu anna fāțimatan zahrā al-karìm binti Muhammad rasūlullāh șallallāh 'alayh wa sallam. anegesi $i(n g)$ sun setuhune ora ana Pengeran anging Allāh; anegesi i(ng)sun setuhuhe dewi Fātimah lin(ta)ng kang mulya puterane wadon Muhammad shallallāh 'alayh wa sallam."

\section{Translation:}

“This is the Fātimah's testimony, those who do not know, men or women, they do not [damaged] their testimony and their belief. This is the testimony: I witness that there is no god save God. And I witness that the beloved Fāțimah is a noble star, the daughter of Muhammad shallallāhu 'alayhi wa sallama." 36

However, the notion of the unity of God, especially in the form of seven gradations of Being (Ar. marātib al-wujūd), penetrated deeper into the mysticism of Java than any other teachings and colored the main form of mysticism until at least the

${ }^{34}$ This translation is entirely from Ibid., 215.

35 It includes the tradition of the feast for the deceased (Jav. slametan or kendhuren) in the $1^{\text {st }}, 7^{\text {th }}, 100^{\text {th }}, 1000^{\text {th }}$, and every year. Belong to the same tradition is the practice of reading religious treatise (Ar. talqin) before burying the death, the commemorating the $10^{\text {th }}$ of the month Ashura, the last Wednesday in the month Safar, and the half of the Sya'ban. Agus Sunyoto, Atlas Walisongo, vol. IV (Depok, 2014), 164.

36 This is my translation of the text. It seems that the Javanese version is an erroneous acquisition of the origin structure Ashhadu anna Fātimah al-Zahrā binta Muhammad 'Ismat Allāh al-Kubrā, "I witness that the bright Fātimah, the daughter of Muhammad, is the great preservation of God." Hasan Hasan Zādah 'Āmilī, Sharh Faṣs Hikmah 'Ișmatiyyah fĩ Kalimah Fạtimah (Qom: Mu'assasat alFarahnakī wa 'Ițtịiā' Rāsānī Tibyān, 1387), 44. 
nineteenth century. AH. John suggests that the source of this concept is Tuhfah al- Mursalah by Muhammad b. Faḍlullāh alBurhānpūrī (c. 952-1029/1545-1620). ${ }^{37}$ Azra argues that it is the reinterpretation of 'Ibn 'Arabī' the Absolute Being (Ar. wäjib alwujūd). ${ }^{38}$

Even though the transferring of this book to Java is still obscure, in Sumatra more traceable history is established. The great Sufi teacher in Medina, Ibrāhīm ibn Hasan al-Kūrānī alShahrazūrī al-Shahrān̄̄ al-Kurdī al-Madanī al-Shāfi'⿳亠丷⿵ (1616-1690 CE), writes a commentary of Tuhfah entitled 'Ithāf al-Dhakī bi Sharh al-Tuhfah al-Mursalah ilā al-Nabī sallallāhu 'alayh wa sallam as a response to 'Abd al-Ra' ûf ibn 'Ali al-Jāwī al- Fanśūrī, one of his Jāwi pupils. ${ }^{39}$ 'Abd al-Ra' ûf is said to have asked his teacher to comment on the doctrine of the seven grades of Being because it raised misunderstandings among Jāw $\bar{\imath}$ Muslim communities. ${ }^{40}$ In addition to this commentary, the teacher is also known to write Jawābāt al-Gharāwīyyah 'an al-Masā'il al-Jāwīyah al-Jahrīyah (Proper and clear answers to the questions from the Jāw $\bar{\imath}$ Lands). ${ }^{41}$

${ }^{37}$ Anthony Hearle Johns, "Malay Sufism: As Illustrated in an Anonymous Collection of 17th Century Tracts," Journal of the Malayan Branch of the Royal Asiatic Society 30, no. 2 (1957): 33. It is unfortunate that in his background to the studies on suluk literatures, Zoetmulder does not pay attention to this mystic nor his Tuhfah which is so important to understand mystical concepts in those suluks. Instead, he selects only great the mystics such as al-Ghazzālī, 'Ibn 'Arabī, and al-Hallāj. Zoetmulder, Pantheism and Monism. Another important rendering of Tuhfah into Javanese language is Or. 5690 96v-103v. From my consultation to the MS., it is written in interlinear translation of the Arabic text.

38 Azyumardi Azra, The Origins of Islamic Reformism in Southeast Asia: Networks of Malay-Indonesian and Middle Eastern "Ulama" in the Seventeenth and Eighteenth Centuries, Southeast Asia Publications Series (Crows Nest, NSW: Asian Studies Association of Australia in association with Allen \& Unwin and University of Hawaii Press, 2004), 136.

39 Otto Loth, A Catalogue of the Arabic Manuscripts in the Library of the India Office, vol. 1 (London: The Secretary of State for India in Council, 1877), 192; Oman Fathurahman, "Itḥāf al-Dhakī by Ibrāhīm al-Kūrānī: A Commentary of Waḥdat al- Wujūd for Jāwī Audiences," Archipel 81, no. 1 (2011): 177-198, https://www.persee.fr/doc/arch_0044-8613_2011_num_81_1_4274.

${ }^{40}$ Fathurahman, "Ithāâf al-Dhakī by Ibrāhīm al-Kūrānī," 181.

${ }^{41}$ Ibid. 
However, Tuhfah is supposed to be known by the Javanese people already in the second half of the 17 th century. ${ }^{42}$ In Tegalarum, on the king's order, Tuhfah was rendered into the Javanese language in Pegon in around the second half of the 18th century.43 The text is beautifully written in Macapat metre. ${ }^{44}$ Therefore, we could safely assume that the doctrine disseminated in Javanese society since the 17th century and found its popularity so the King of Panggungwati of Tegal-arum asked a santri to rendered the treatise into Javanese. ${ }^{45}$

This doctrine is creatively interpreted by the Javanese court poets and reaches its culmination in the hand of Ranggawarsita (1802-1873), especially in his Serat wirid hidayat jati. In the relation of Essence and Attributes of Being, the text teaches that there are seven steps each of which correlates with the seven grades, namely Shajarah al-Yaqīn, Nūr Muhammad, Mir'ah al-haya'i, Rūh Iḍafi, Kandil, Dharrah, and hijab. ${ }^{46}$

${ }^{42}$ Anthony Hearle Johns, The Gift Addressed to the Spirit of the Prophet, vol. 1, Oriental monograph series (Canberra: Australian National University, Centre of Oriental Studies, 1965), 23.

${ }^{43}$ In his translation and commentary to this Javanese Tuhfah, John consulted to several MSS., namely Add 12305 of British Museum, Or. 5594, and Zoetmulder translation of Or. 1795. As indicated, at some points they differ widely. I consult to Or. 5594 and found that he preferred other version at least in the early stanzas. Johns, The gift addressed to the spirit of the Prophet, 21-23; Or. 5594, 70.

${ }^{44}$ Johns, The Gift Addressed to the Spirit of the Prophet, 25. It is of interest that many Pegon MSS. held in Leiden are also written in poetic Macapat metre, but little is investigated by scholars.

${ }^{45}$ It is a reasonable supposition since the text is written in Pegon which is the form of writing in pesantren tradition until today. However, the history of Pegon writing is a subject that is little studied, if any.

46 Simuh, Mistik Islam Kejawen Raden Ngabehi Ranggawarsita: Suatu Studi terhadap Serat Wirid Hidayat Jati (Jakarta: UI-Press, 1988), 234-235. When Ranggawarsita explaines the relation between God and servants, he makes an allusion of three thrones of God with physical parts of the human body. The first throne is Baitul Makmur. The seven grades from the exterior to the interior are Head, Brain, Manik, Budi, Nafsu, Suksma, and Rahsa. The second throne is Baitul Muharram. The seven grades are Chest, Heart, Budi, Jinem, Suksma, and Rahsa. The third throne is Baitul Muqaddas. The seven grades here are Penis, Testicles, Mani, Madi, Wadi, Manikem, and Rahsa. For women, they are Vulva, Clitoris, Mani, Madi, Wadi, Manikem, and Rahsa. Simuh, Mistik Islam 


\section{Self-disclosure of God: Manunggaling Kawula lan Gusti}

The doctrine of Unity or unification of being (Ar. wahdah al$w u j \bar{u} d$ ) has encouraged the fierce debate among not only the outside observers but also the Sufis themselves. For the former, on the one hand, some Western Orientalists misunderstand and pejoratively categorize the doctrine into pantheism, monism, and similar Western philosophical concepts with all theological abominations defaming the doctrine and the experience of it. ${ }^{47}$ For example, Nicholson writes about the concept of Light, Knowledge and Love, the principles of Sufism:

"Ultimately they rest upon a pantheistic faith which deposed the One transcendent God of Islam and worshiped in His stead One Real Being who dwells and works everywhere, and whose throne is not less, but more, in the human heart than in the heaven of heavens." ${ }^{4}$

Furthermore, Duncan Black Macdonald makes a new category on what he calls "Pantheistic schools" of Sufism on which he includes great Sufis such as 'Abū Yazīd al- Bisțāmī (d. 874) and Ḥusayn bin Manșūr al-Ḥallāj (d. 922). ${ }^{49}$ In their narration, these authors indicate that the heretical condemnation of Muslim law scholars (Ar. 'ahl al- figh) to these Sufis automatically justify their categorization of pantheist or monist; without fully aware that no Muslim law condemned the Sufis as "heretics" because of both pantheism or monism.

On the other hand, they are scholars who depose the term pantheism to the metaphysical doctrines of the East, including Sufism. For this, Titus Burckhardt writes:

Kejawen, 237-39. In MS. Or. 5592, a tree-bark paper, seemingly as old as $18^{\text {th }}$ century, p. 177, "Bismillāhirraḥmānirraḥim Iyo badan iyo nyowo iyo Allah iyo Rohsyo iyo Ahmad iyo Rosulullah. Badaningsun Sirr." (In the Name of God, the Compassionate, the Merciful [It is, na] body, soul, Allah, Spirit, Ahmad, the Messenger of God. My body is the spirit [or hidden, na]).

47 Seyyed Hossein Nasr, Islamic Philosophy from Its Origin to the Present: Philosophy in the Land of Prophecy, SUNY Series in Islam (Albany: State University $\begin{array}{llll}\text { of New } & \text { York 2006), } & \text { 75, }\end{array}$ http://catdir.loc.gov/catdir/toc/ecip0517/2005023943.html.

48 Reynold Alleyne Nicholson, The Mystics of Islam (London: GBell and Sons, 1914), 8.

${ }^{49}$ Duncan B. Macdonald, Development of Muslim Theology, Jurisprudence and Constitutional Theory (Beirut: Khayats, 1965), 183-185. 
"Pantheism only conceives of the relationship between the Divine Principle and things from the one point of view of substantial or existential continuity, and this is an error explicitly rejected by every traditional doctrine. ... He is in reality beyond compare and therefore distinct from everything manifested, but without the possibility of anything being “outside" or "beside" Him."50

The Philosophers and Sufis' views on this matter are also divergent. Those are Sufis who stand silent on the subject, such as Shaykh Abū al-Hasan al-Shādhilī. Their view is that the doctrine is meant for the spiritual elite of the elite (Ar. khawwās al-khawwās), therefore its exposition for the general people (Ar. 'awwām) should be limited, at least it must be explained only in an implicit way. ${ }^{51}$ Kiai Soleh Darat holds the same position that without transgressing to the idea itself, he covers the general people from accessing this doctrine. ${ }^{52}$ Some others strongly oppose the doctrine such as a Qādirī Sufi, Taqī al-Dīn Ibn Taymiyyah (d. 1328) especially to the doctrine as expounded by Ibn 'Arabī (d. 1240).53

Now Javanese concept of manunggaling kawula lan Gusti is the local expression for the understanding as expounded by Burckhardt above that - in Frithjof Schuon words - "the world is mysteriously plunged in God". ${ }^{4}$ This certainty is achieved through the emphasis on the transcendence God in every Javanese mystical treatises. Even in the term itself, manunggaling kawula lan Gusti, the names of the two are mentioned bearing the idea of the inferior servants and the Superior God. In one of the oldest Islamic MSS, Suluk Wujil, Sunan Bonang in his beginning of the secret teaching is said to advise, "... And be conscious and certain that you are not The Real One, and The Real One is not you; those who

${ }^{50}$ Titus Burckhardt, Introduction to Sufi Doctrine (World Wisdom, Inc, 2008), 17.

${ }^{51}$ Nasr, Islamic Philosophy, 75-76.

${ }^{52}$ Muhammad Soleh al-Samarani, Majmū'at al-Sharì'at al-Kāfiyat li al-'Awwām (Semarang: Toha Putera, n.d.).

${ }^{53}$ Nasr, Islamic Philosophy, 76.

${ }^{54}$ Frithjof Schuon, Language of the Self, 2nd ed. (Bloomington, Ind: World Wisdom, 2003), 139. 
know themselves are as if they know God." 55 In addition in the admonition of Seh Bari, a saint called Sek Běntong is said to explain, "He who is called Allah is Allah, with two modes of being indeed, but without duality." 56 Even in the texts which are suggested as containing so-called "Radical monism", the eternal God is shown everywhere. ${ }^{57}$ For example, "The Almighty God has the quality of merciful. His Being is the life without source. His Being has no material form." 58

However, some scholars may argue that there also the idea of union between the servant and the Lord or that (Cen. Canto 154)"... budi and the Essence of God being not different in their unity." 59 However, this concept should be understood under the idea that is stated before that (Cen. Canto 154) "... the entering of the names is something secret which can not be attained by the physical senses, nor made public,...". ${ }^{60}$ In other words, this knowledge is achieved not from the process of ratiocination but the intellection and inner experience. ${ }^{61}$

This idea is based on the heart of the Islamic teaching (Ar. tawhìd). God is the only One who possesses Being (Ar. wujūd). In other words, all other than He has no being on their own. In this

55 Stanza 11 Suluk Wujil as translated in Raden Mas Ngabehi Purbatjaraka, Ajaran Rahasia Sunan Bonang: Suluk Wujil (Jakarta: Proyek Penerbitan Buku Sastra Indonesia dan Daerah, 1985), 17. The part quoted is

“...Kawruhana den estu Sariranta pan dudu jati Kang jati dudu sira Sing sapa puniku Weruh rekeh ing sarira

Mangka sasat wruh sira maring Yang Widi"

${ }^{56}$ Drewes, An Early Javanese Code, 47.

${ }^{57}$ This is the title of a chapter in Zoetmulder, Pantheism and Monism, 209238.

58 Zoetmulder mistranslates walkayatun bilarokin which is a local Arabic pronunciation of hayāt(un) bilā rūh(in) and translated by the author of Serat Centhini into "uripe tanpa nyawa" in a sense that "(He is) the Ever- Living without outside source". He also mistranslates the word "kahanan" which in this context means "physical appearance" or "material world" that you can see with your eyes, not "substratum" as he translates and be confused about that with placing "?" at the end of the line. The word "kahanan" is still a living word in the Javanese language. Ibid., 210, and 213.

${ }^{59}$ Ibid., 214.

${ }^{60}$ Ibid., 213.

${ }^{61}$ Nasr, Islamic Philosophy, 74. 
context, the discussion of the two becomes one does not even rise because since the beginning, wujūd is only God's and all existents appear to possess it only through the "Breath of the Compassionate" (Ar. nafas al-rahmmān). In Javanese mystical treatises, many ways are employed to point to this reality. One of the best is found in the Serat Tuhfah (stanza 10):

"Know that it is the being of the Reality

which is the Reality of all existents, and their hidden reality

which is within the [Divine] Knowledge

and is called the Fixed Prototypes;"62

This teaching, in general, is not only found in court poets as suggested by several scholars which refer mainly or only to their treatises, but it is the teaching of the pesantren tradition. I consult to pegon MSS. in Leiden most of which are not studied yet; the mystical teaching is found in many MSS. ${ }^{63}$ For example, in a Javanese tree-bark paper (Jav. dluang) with code Or. 5609, which contains a book entitled Kitab Insan Kamil (the Book of the Perfect Man), we find this doctrine as well.

Text. Or. 5609, p. 11:

"Anapun haqeqoteng wnjud iku sifat partingkah kang wajib ing drat selanggenge. Drat iku tanpa karana kalawan sawiji-wiji tegese iya dzat iya sifat. Anapun haqeqoteng sifat salbiyah iku anguculi kang ora layaq ing wujude Allah ta'ala. Sifat qidam iku anguculi andhibin ing Allah ta'ala."

\section{Translation:}

"The nature of Being is to attribute the necessity for the Essence [that is Wäjib al-wujüd, na] The Essence is without any cause. It means It is Essence and Attributes [they are One without separation, na]. ${ }^{64}$ The

62 This is entirely from Johns, The Gift Addressed, 1:33. The text is translated from:

"Kawruhana wudjud Kang Sedjati,

sedjatining sakéhing maudjudat

lan hakékaté batine;

kang anéng dalem ilmu

ingaranan a'jan kang thabit"

${ }^{63}$ It seems to me that scholars of Javanese mystical doctrine belittle these abundant sources which are important to reveal the complexity of the Javanese beliefs, especially from the pesantren tradition.

${ }^{64}$ Compare with: 
nature of the Negative Attributes is to detach attributes which are improper for God. The attribute of the Eternity detaches [the idea of having, na] beginning for God."'65

\section{The Spiritual Journey: Sharī’ah, Ṭarīqah, Ḥaqīqah}

Javanese mystical authors are always aware that this doctrine is "something secret" and may lead someone into the Fire. In other words, this doctrine is not meant for everybody. ${ }^{66} \mathrm{It}$ is found in the oldest MS. and the most recent, this "secret aspect" (Jav. ngelmu rahasya) is emphasized. In Suluk Wujil stanza 5, Sunan Bonang says to Wujil who asks the knowledge of unity, "O, Wujil, how naughty you are! You ask something unusual." ${ }^{67}$ In the nineteenth century, which seems to be the last composition on this genre, Ranggawarsita tells that this teaching called ilmu makrifat (gnosis) is allowed to be taught only by elite intellectuals among Walis. ${ }^{68}$ In the introduction of Ranggawarsita's Serat Wirid Hidayat Jati, Monggopradoto says,

“... In those days, this Serat is considered sacred and its teaching is venerated and hidden. It is not allowed or let no others hear about it.

"As for wujūd, it is itself an attribute of the Divine Reality (Ar. al-Haqq) and identical to Its Essence. Divine Knowledge, while ultimately being none other than the Divine Essence, is also none other than emanation." Nasr, Islamic Philosophy, 176.

65 This is my own translation of the text.

${ }^{66}$ It is a famous wisdom for Sufis that some doctrines on esoteric knowledge are not meant for everyone. Ghazzālī says, "not every religious secret could be disclosed nor exposed; And not every reality could be revealed nor explained." Al-Ghazzālī, Mishkāt al-Anwār , 116-117.

${ }^{67}$ The great Sunan is also said to warn Wujil in stanza 10, "If because of my words you go into the Fire, so I will take your place [in the Fire, na], not you". This is my translation to Purbatjaraka, Ajaran Rahasia, 16-17.

68 Simuh, Mistik Islam, 225. In the reign of Sultan Agung he mentions nine walis who are allowed to teach this namely 1) Panembahan Purubaya; 2) Panembahan Ratupekik; 3) Panembahan Jurukithing; 4) Pangeran Kadilangu; 5) Pangeran Kudus; 6) Pangeran Tembayat; 7) Pangeran Kajoran; 8) Pangeran Wangga; 9) Panembahan Juminah. It is not clear in his Serat Wirid who has taught him and given the consent to teach this secret doctrine. 
The idiom says: Suket godhong aja krungu [let no grass nor leaves hear it, na]." 69

Those who crave to experience this doctrine are demanded to follow a path or set of rituals (Jav. ngelmu) on Sharīah and Tarīgah. This aspect is mainly ignored by Western scholars, unfairly paying more attention to the achievement, directly to Haqiqah. In Serat Centini it is shown by, "the deepest essence of the secret, which one seeks to bring to realization, is by educating one's budi. ${ }^{70}$ [To achieve this, na], therefore exist the sciences of Sharī'ah, Tarīqah, Haqīqah journeying to Ma'rifah." 71

Sharì'ah, Tarīqah, and Haqīqah in Javanese mystical texts seem to be employed as an idiomatic phrase for living someone's life in accordance with God's sacred law. It is also employed as requirements to take one's spiritual journey. As the vehicle, prayers (Jav. sembahyang; Ar. salāh) are most important. This prayer is seen not from the legalist point of view which is seen as dry by spiritual seekers, but it is the ritual in which someone ascends to God. ${ }^{72}$ In Suluk Wujil, it is said that what is more important than canonical prayers is the always consciousness that someone is before the Lord. ${ }^{73}$ It teaches that those who pray must know the "object" they worship and then they are always in the state of inner praying to God (Ar. șalāh dā'im). ${ }^{74}$ Instead of a manual book on prayer, this esoteric idea of prayers seems to be popular at some point in the history of Javanese Islam, because it

69 This my translation of Monggopradoto's introduction to Ranggawarsita, Hidayat Jati (Surakarta: Honggopradoto, 1941), 3, as quote in Simuh, Mistik Islam, 362.

70 'Aql, Arabic, or "intellect" in the traditional sense.

${ }^{71}$ This is my revision to Zoetmulder, Pantheism and Monism, 210-213. I edit some word in Zoetmulder's translation. The word "wurunge" means "to educate" or "to teach". Compare with "wuru"' which is still in usage. Zoetmulder also does not translate "myang" which is still in use today to mean "to take a journey", especially in fisherman's family "miyang" means "their journey to the sea to fish". Compare with miyang and menyang in today's Javanese language.

${ }^{72}$ In this regards, it is worthy to consider the hadith of the prophet, "the canonical prayer is the ascension of the believers."

${ }^{73}$ Purbatjaraka, Ajaran Rahasia, 58.

${ }^{74}$ Sri Harti Widyastuti, Suluk Wujil: Suntingan Teks dan Tinjauan Semiotik (Semarang: Kelompok Studi Mekar, 2001), 234. 
is also mentioned in many MSS. ${ }^{75}$ It also describes pilgrimage to Mecca in esoteric sense that this journey demands for difficult and "expensive" preparation, namely bravery, devoutness, sincerity, and determination. It emphasizes that one may physically reach Mecca but one does not reach the goal. Only those who have these preparations would be a saint when they arrive at Ka'ba. ${ }^{76}$

The most important of all, however, is that the truth traveler (Ar. sālik), ${ }^{77}$ in practicing this esoteric knowledge, they must be under the guidance of a teacher. As in all Sufi orders, they must follow what their masters order him. Those who want to practice this teaching without the guidance of a master, their master is Satan. In addition, they must discipline themselves during their journey. In Suluk Wujil this strict discipline is a path through which they know themselves only from which they then know God..$^{78}$ The goal of such discipline is the refinement of characters of the spiritual travelers. It includes to living in accordance with the sharia, to restrain the self that commands to evil, to guard their vision, and to sleep little.

Translation of Suluk Wujil stanza 24:

"Some people feel that they have known God, but their characters are in contradiction with the [noble, na] principle. They do not obey the rules to restrain the impure desire, tossing aside the virtuous life. Truly, those who know Him are able to restrain their impure desire. Days and nights, they discipline their visual sense, and sleep is prevented by them." ${ }^{\prime 79}$

However, it cannot be denied that the main concern of Javanese mystical teaching is given to the achievement of the spiritual journey. Less is given to the supplies to this journey. The exposition on the nature of the unity between servant and Lord

75 Contemplative quality of the Sacred Law is always the heart of attention in Sufism.

${ }^{76}$ Widyastuti, Suluk Wujil, 237.

77 Sălik and suluk are derived from the same root, $s-l-k$ which means "to travel". It bears the meaning that suluk literature is a book of guidance for those who crave to travel to God.

78 Stanzas 23-25, Purbatjaraka, Ajaran Rahasia, 20. This is a famous phrase in the Sufi tradition attributed to the prophet, "Man 'arafa nafsahu 'arafa Rabbahu" which means "those who know themselves know God of the self."

${ }^{79}$ This is my translation to Ibid. 
floods most pages of Javanese mysticism, while the compliance to the rules of this journey appears once in a while.

It is certain that in one of the character of Javanese mysticism in the era of Islam are the deeper penetration to incorporate Islamic teaching by referencing to Islamic mystical books. Even though the relation between the Ghazzâlian school of mysticism and the school of Ibn 'Arabì could not be fully described yet, it is safe to assume that Javanese mysticism sees these two forms grow in its mystical soil. The fundamental distinction between the two lies at the issue of wahdah al-wujüd on which the former does not expose, while the other is a keen supporter. However, their goal is the same to make the journey to God or within God. However, in the case of Javanese mysticism, the wahdah al-wujūd school has long established itself as the predominant school of mysticism. Not only seen in the suluk literature written in Javanese script, this doctrine is also abundant in pegon script, indicating its popularity in the pesantren tradition. The last character is that this kind of mysticism - as shown in the suluk literature - put a strong emphasis on the strict religious ethics including the rein in the behavior, guarding the visual sense, and sleeplessness.

\section{Conclusion}

Simuh concludes in his dissertation on the 19th-century Javanese mysticism by saying, "In response to the growing body of Islamic literature, for example, the mystical teaching and the dissemination of morals are preferable by the Javanese poets, not the teaching of sharia." 80 It seems that he was too vulgar to make this sharp distinction. Even though the emphasis on mystical experience and morals dominate the Javanese esoteric literature, it emerges not only in poet community but also in pesantren community. Many manuscripts in Pegon, which is the strong indication of their circulation in pesantren tradition, support this statement. Indeed, the rendering of Tuhfah as he quotes from John's dissertation comes in poetic Javanese form, which indicates its author, but the other manuscript (Or. $569096 \mathrm{v}-103 \mathrm{v}$ ) is an interlinear translation of the Arabic text which is the pesantren

${ }^{80}$ Simuh, Mistik Islam, 377. 
traditional way of translation. ${ }^{81}$ Here too, the attention to the sharia is less shown.

Instead of strict distinction, it is more likely that the two intentions on sharia and mystics are intertwined to each other. It is shown that the sharia is never entirely left out in Javanese mystical teachings. It appears in the form of esoteric prayers, pilgrimage to Mecca, isolation from worldly life, and watching five senses. This less attention to sharia is due to the fact that the idea is meant for the elite of spiritual travelers.

\section{References}

'Āmilī, Hasan Hasan Zādah. Sharḥ Faṣṣ Hikmah 'Iṣmatiyyah fì Kalimah Fātimah. Qom: Mu'assasat al-Farahnak̄̄ wa 'Iț̣ilā' Rāsānī Tibyān, 1387.

Al-Ghazzālī, Abū Hāmid Muḥammad. Mishkāt al-Anwāar wa Miṣfāt al-Asrār. Edited by 'Abd al-'Azīz 'Izz al-Dīn Al-Sayrawān. Beirut: Mazra'at Binābat al-Īmān, 1407.

Al-Sālimī, Abū Shakūr. al-Tamhīd fì Bayān al-Tawhīd. Delhi, 1892.

Azra, Azyumardi. The Origins of Islamic Reformism in Southeast Asia:

Networks of Malay-Indonesian and Middle Eastern "Ulama" in the Seventeenth and Eighteenth Centuries. Southeast Asia Publications Series. Crows Nest, NSW: Asian Studies Association of Australia in association with Allen \& Unwin and University of Hawaii Press, 2004.

Becker, Judith O. Gamelan Stories: Tantrism, Islam, and Aesthetics in Central Java. 2nd ed. Monographs in Southeast Asian Studies. Arizona: Program for Southeast Asian Studies, Arizona State University, 2004.

Burckhardt, Titus. Introduction to Sufi Doctrine. World Wisdom, Inc, 2008.

Chittick, William C. Self-Disclosure of God: The Principles of Ibn Al'Arabi's Cosmology. Albany: SUNY Press, 1998.

Dhofier, Zamakhsyari. "The Pesantren Tradition: The Role of the Kyai in the Maintenance of Traditional Islam in Java." Unpublished Dissertation. The Australian National University,

${ }^{81}$ The same way of translation happens in Or. 5592 pp. 146-176. Here, the text Suluk Sujinah in Javanese script is given interlinear translation in Pegon. 
1999.

Drewes, G. W. J. An Early Javanese Code of Muslim Ethics. The Hague: Nijhoff, 1978.

- - - "Javanese Poems, Dealing with or Attributed to the Saint of Bonan," 1968.

- - , ed. The Admonitions of Seh Bari: A 16th Century Javanese Muslim Text Attributed to the Saint of Bonain. The Hague: Martinus Nijhoff, 1969.

Fathurahman, Oman. "Ithāf al-Dhak̄̄ by Ibrāhīm al-Kūrān̄i: A Commentary of Waḥdat al- Wujūd for Jāwī Audiences." Archipel 81, no. 1 (2011): 177-198.

https://www.persee.fr/doc/arch_0044-

8613_2011_num_81_1_4274.

Geertz, Clifford. The Religion of Java. Phoenix ed. Chicago: University of Chicago Press, 1976.

Hodgson, Marshall G. S. The Venture of Islam: The Classical Age of Islam. Vol. 1. Chicago: The University of Chicago Press, 1997.

- - - The Venture of Islam Conscience and History in a World Civilization: The Expansion of Islam in the Middle Periods. Vol. 2. Chicago: University of Chicago Press, 1974.

Johns, Anthony Hearle. "Malay Sufism: As Illustrated in an Anonymous Collection of 17th Century Tracts." Journal of the Malayan Branch of the Royal Asiatic Society 30, no. 2 (1957): 3110.

- - - . The Gift Addressed to the Spirit of the Prophet. Vol. 1. Oriental monograph series. Canberra: Australian National University, Centre of Oriental Studies, 1965.

Kraemer, H. "Een Javaansche Primbon Uit de Zestiende Eeuw." Thesis. Leiden University, 1921.

Loth, Otto. A Catalogue of the Arabic Manuscripts in the Library of the India Office. Vol. 1. London: The Secretary of State for India in Council, 1877.

Macdonald, Duncan B. Development of Muslim Theology, Jurisprudence and Constitutional Theory. Beirut: Khayats, 1965.

Mas'ud, Abdurrachman. Dari Haramain ke Nusantara: Jejak Intelektual Arsitek Pesantren. Jakarta, Indonesia : Kencana, 2006. Nasr, Seyyed Hossein. Islamic Philosophy from Its Origin to the Present: Philosophy in the Land of Prophecy. SUNY Series in 
Islam. Albany: State University of New York Press, 2006. http:/catdir.loc.gov/catdir/toc/ecip0517/2005023943.html.

Nasuhi, Hamid. Serat Dewaruci: tasawuf Jawa Yasadipura I. Jakarta:

Ushul Press etc, 2009.

Nicholson, Reynold Alleyne. The Mystics of Islam. London: GBell and Sons, 1914.

Purbatjaraka, Raden Mas Ngabehi. Ajaran Rahasia Sunan Bonang: Suluk Wujil. Jakarta: Proyek Penerbitan Buku Sastra Indonesia dan Daerah, 1985.

Ranggawarsita. Hidayat Jati. Surakarta: Honggopradoto, 1941.

Ricklefs, M. C. Mystic Synthesis in Java: A History of Islamization from the Fourteenth to the Early Nineteenth Centuries. Norwalk CT: EastBridge Signature Books, 2006.

Schimmel, Annemarie. Deciphering the Signs of God: A Phenomenological Approach to Islam. Albany, NY: State University of New York Press, 1994.

Schrieke, B.J.O. "Het Boek van Bonang." Thesis. Leiden University, 1916.

Schuon, Frithjof. Language of the Self. 2nd ed. Bloomington, Ind: World Wisdom, 2003.

Simuh. Mistik Islam Kejawen Raden Ngabehi Ranggawarsita: Suatu Studi terhadap Serat Wirid Hidayat Jati. Jakarta: UI-Press, 1988.

Soleh al-Samarani, Muhammad. Majmū'at al-Sharī’at al-Käfiyat li al'Awwām. Semarang: Toha Putera, n.d.

Steenbrink, Karel A. Beberapa Aspek tentang Islam di Indonesia Abad ke-19. Jakarta: Bulan Bintang, 1984.

Sunyoto, Agus. Atlas Walisongo. Vol. IV. Depok, 2014.

Supriyadi, Hamam. "The Meanings of Sanskrit Loanwords in Thai and Javanese Languages." Humaniora 23, no. 3 (2011): 280-289. Widyastuti, Sri Harti. Suluk Wujil: Suntingan Teks dan Tinjauan Semiotik. Semarang: Kelompok Studi Mekar, 2001.

Woodward, Mark R. Islam in Java: Normative Piety and Mysticism in the Sultanate of Yogyakarta. Tucson: The University of Arizona Press, 1989.

Zoetmulder, P.J. Pantheism and Monism in Javanese Suluk Literature: Islamic and Indian Mysticism in an Indonesian Setting. Translated by M.C. Ricklefs. Leiden: KITLV Press, 1995. 